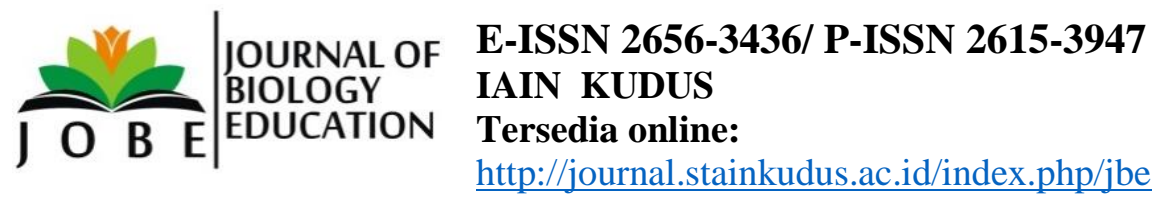

\title{
Menstruasi: Pengalaman dan Pengetahuan Siswa SD Negeri Prawoto 01
}

\author{
1.Cheppy Fadella, 2. Didi Nur Jamaludin ${ }^{2)}$ \\ 1) Mahasiswa Tadris Biologi IAIN Kudus \\ 2) Dosen Tadris Biologi IAIN Kudus \\ cheppyfadella123@gmail.com, bioedu88@gmail.com
}

\begin{abstract}
ABSTRAK
Penelitian bertujuan untuk mendiskripsikan pengalaman dan pengetahuan menstruasi siswa Sekolah Dasar (SD) Negeri Prawoto 01, dengan pendekatan penelitian kualitatif jenis studi kasus. Penelitian ini menggunakan sampel sebanyak 63 siswa dari seluruh populasi siswa perempuan kelas IV, V dan VI. Berdasarkan hasil penelitian,rata-rata $14 \%$ siswa mengetahui menstruasi, $35 \%$ sedikit mengetahui mensruasi, 5I\% siswa tidak memiliki pengetahuan sedikitpun tentang menstruasi. Faktor yang mempengerahui sedikitnya pengetahuan tentang pendidikan mentruasi disebabkan karena keterbatasan informasi diantaranya dari oran tua, guru dan pengalaman pribadi. Hasil penelitian dari pengalaman menstruasi menunjukkan bahwa rata-rata $11 \%$ siswa SD telah mengalami menstruasi dengan rincian mulai kelas IV sebanyak 13\%, kelas V sebanyak 5\% dan kelas VI sebanyak 15\%. Oleh sebab itu pendidikan menstruasi perlu dikembangkan di Sekolah Dasar dengan melibatkan peserta didik dan orangtua.
\end{abstract}

Kata Kunci: Menstruasi, Sekolah Dasar, Pengalaman dan Pengetahuan

\begin{abstract}
Research to describe the experience and knowledge of menstruation, students of Elementary School (SD Prawoto 01). This research is used qualitative research in the case study type. This study used a sample of 63 students from all class $I V, V$ and VI students. Based on the results of the study, an average of $14 \%$ of students knew menstruation, 35\% knew little about menstruation, 5I\% of students did not have the slightest knowledge of menstruation. Factors influencing the knowledge of educational education due to limited information from parents, teachers and personal experience. The results of the menstrual experience show that on average $11 \%$ of elementary school students have completed class of IV by $13 \%$, class of $V$ by $5 \%$ and class of VI by 15\%. Therefore menstruation education needs to be developed in elementary schools by involving students and parents.
\end{abstract}

Keywords: Menstruation, Elementary School, Experience and Knowledge 


\section{PENDAHULUAN}

Masa remaja adalah masa yang diawali dengan adanya tanda-tanda pubertas yang berujung pada tingkat tercapainya kematangan organ reproduksi. Pubertas dalam hal ini yaitu perubahan fisik yang menonjol, perubahan pola pikir yang awalnya takut menjadi berani dan juga perubahan hormon pada sel kelamin (Triyanto, 2010). Hormon merupakan zat kimia yang diproduksi oleh sistem endokrin dalam tubuh dan berfungsi untuk membantu mengendalikan hampir semua fungsi tubuh seperti pertumbuhan, metabolisme dan sistem reproduksi.

Remaja putri, masa pubertas ditandai dengan peristiwa menstruasi. Menstruasi biasanya diawali pada umur minimal 10 tahun. Akan tetapi, pada masa milenial sekarang ini tidak menutup kemungkinan menstruasi terjadi sejak dini yaitu di bawah umur 10 tahun. Dikutip dari berita liputan 6 yang memberitakan bahwa jumlah remaja putri yang mengalami menstruasi pertama (menarche) di bawah umur 10 tahun semakin meningkat. Dan berdasarkan research di luar negeri, sekitar 15 dari 100 ribu anak yang menstruasi cepat (di bawah umur 10 tahun) semakin banyak (Desideria, 2017).

Perbedaan umur saat menarche ini dipengaruhi oleh beberapa faktor. Menurut Frida Susanti (2017) satgas Remaja Ikatan Dokter Anak Indonesia (IDAI) dalam berita liputan 6 mengungkapkan bahwa faktor yang mempengaruhi anak mengalami masa menstruasi pada umur tertentu yaitu polusi udara, penggunaan botol air minum dalam kemasan yang terlalu sering dan hormon dalam otak yang yang aktif terlalu dini.

Semakin meningkatnya angka remaja putri yang mengalami menarche pada usia dini, seharusnya juga harus diimbangi dengan pengetahuan menstruasi sejak dini pula. Agar mereka dapat mempersiapkan diri secara emosi dan psikologi ketika masa menstruasi terjadi. Berdasarkan hasil penelitian Pujiasti dkk (2017) menunjukkan bahwa sebagian besar siswa yang telah mengalami menarche pada usia dini mengalami kecemasan hebat dan rasa takut ketika mengalami menstruasi (Pujiati, dkk, 2017).

Kecemasan tersebut timbul karena mereka belum memiliki pengetahuan tentang menstruasi. Akibatnya, segala macam aspek yang meliputi psikologi, mental dan emosi siswa belum siap menerimaperubahan yang terjadi dalam 
tubuhnya.Hal ini mengartikan bahwa pengetahuan menstruasi sejak dini menjadi sangat penting bagi siswa yang akan menginjak masa remaja untuk menghadapi masa pubertas. Berdasarkan pemaparan tersebut, peneliti merasa tertarik untuk melakukan penelitian mengenai menstruasi di SD Negeri Prawoto 01 dari mulai pengetahuan dan pengalaman siswa.

\section{METODE PENELITIAN}

Penelitian ini adalah penelitian kualitatif deskriptif. Kualitatif deskriptif adalah penjabaran hasil penelitian secara apa adanya berdasarkan hasil pengamatan dan juga hasil data yang diperoleh. Metode pengambilan data penelitian ini yaitu dengan menggunakan kuesioner atau angket. Sampel dalam penelitian ini yaitu siswa perempuan sejumlah 63 siswa dengan rincian sebagai berikut kelas IV sejumlah 23 siswa, kelas V sejumlah 20 siswa dan kelas VI sejumlah 20 siswa. Fokus pengambilan data tentang pengalaman dan pengetahuan siswa tentang menstruasi. Pengambilan sampel dalam penelitian ini yaitu dengan menggunakan teknik sampling jenuh yakni populasi menjadi sampel dalam penelitian. Waktu pelaksanaan penelitian dan pengolahan data yaitu pada bulan Juli-Agustus 2019 di SDNegeri Prawoto 01, Kecamatan Sukolilo, Kabupaten Pati.

\section{HASIL DAN PEMBAHASAN}

\section{Deskripsi Hasil Penelitian}

Tabel 1. Persentase Pengalaman Menstruasi Siswa

\begin{tabular}{ccccc}
\hline \multirow{2}{*}{ No } & Kelas & \multicolumn{2}{c}{ Persentase (Jumlah) } & Total Siswa \\
\cline { 3 - 5 } & & Sudah & Belum & \\
\hline 1 & IV & $13 \%(3)$ & $87 \%(20)$ & 23 \\
\hline 2 & V & $5 \%(1)$ & $95 \%(19)$ & 20 \\
\hline 3 & VI & $15 \%(3)$ & $85 \%(17)$ & 20 \\
\hline \multicolumn{2}{l}{ Rata-rata } & $11 \%(7)$ & $89 \%(22)$ & \\
\hline
\end{tabular}

Berdasarkan hasil penelitian yang telah digambarkan pada tabel di atas, diketahui bahwa siswa kelas IV, V dan VI SD Negeri Prawoto 01 sebagian kecil (minoritas) telah mengalami menstruasi pertama(menarche) dengan frekuensi yang berbeda. Tiga dari dua puluh tiga siswa kelas IV telah mengalami menarche 
ketika umur 9 tahun. Berbeda dengan kelas $\mathrm{V}$, satu dari dua puluh siswa telah mengalami menarche ketika umur 10 tahun. Sedangkan siswa kelas VI, tiga dari dua puluh siswa telah mengalami menarche ketika umur 11 atau 12 tahun.

Berkaitan dengan penjabarandi atas, diketahui bahwa sejumlah $4,8 \%$ siswa SD Negeri Prawoto 01 yang mengalami menarche lebih awal ( 9 tahun). Sedangkan siswa yang mengalami menarche normal dengan rata-rata umur 10-12 tahun sebanyak 6,3\%. Persentase ini tidak jauh berbeda dengan hasil Riskesdas tahun 2010 yang menunjukkan bahwa sebanyak 5,2\% siswa Sekolah Dasar (SD) mengalami pengalaman pertama menstruasi di umur 9-10 tahun (Nurmawati \& Erawanti, 2018).

Hasil studi lapangan, rerata siswa kelas IV, V dan VI SD Negeri Prawoto 01 yang telah mengalami menstruasi menunjukkan pribadi yang berbeda dengan siswa yang belum mengalami mensrtuasi. Siswa yang telah mengalami menstruasi, lebih bersikap tertutup (introvet) dan lebih sering berdiam diri di dalam kelas. Mereka juga menunjukkan sikap yang lebih perhatian terhadap penampilan dan dominan memiliki perasaan malu terhadap lawan jenis. Hal ini berbeda dengan siswa yang belum mengalami menstruasi, sikapnya cenderung aktif dan cuek terhadap penampilan.

Berdasarkan tanggapan siswa ketika mengalami menarche, sebagian besar menjawab kaget, takut, khawatir dan gelisah saat menarche terjadi. Rasa kaget, takut, khawatir dan gelisah tersebut disebabkan karena pengetahuan tantang menstruasi bagi siswa masih sangat sedikit. Untuk mengatasi rasa kegelisahannya, Mereka bertanya kepada orang tuanya. Akan tetapi, hanya sebagian kecil orang tua yang menjelaskan menstruasi secara detail yang berdampak pada minimnya pengetahuan siswa tentang menstruasi. Hal ini diperkuat dnegan tabel kedua yang akan dijelaskan sebagai berikut.

Tabel 2. Persentase Pengetahuan Siswa tentang Menstruasi

\begin{tabular}{cccccc}
\hline \multirow{2}{*}{ No } & Kelas & \multicolumn{3}{c}{ Persentase (Jumlah) } & Total Siswa \\
\cline { 3 - 5 } & & Mengetahui & Sedikit & Tidak & \\
\hline 1 & IV & $22 \%(5)$ & $30 \%(7)$ & $48 \%(11)$ & 23 \\
\hline 2 & V & $5 \%(1)$ & $5 \%(1)$ & $90 \%(18)$ & 20 \\
\hline 3 & VI & $15 \%(3)$ & $70 \%(14)$ & $15 \%(3)$ & 20 \\
\hline \multicolumn{2}{l}{ Rata-rata } & $14 \%(9)$ & $35 \%(22)$ & $51 \%(32)$ & \\
\hline
\end{tabular}


Berdasarkan hasil penelitian diatas, menunjukkan bahwa rata-rata $51 \%$ siswa tidak mengetahui pengetahuan tentang menstruasi. Berdasarkan hasil pengisian angket, siswa tersebut memberikan tanggapan tanpa disertai dengan penjelasan. Sedangkan siswa yang mengetahui menstruasi memberikan tanggapan yang berbeda-beda di antaranya; menstruasi merupakan darah, darah kotor dan orang yang sedang menstruasi tidak boleh melaksanakan sholat (sebagian besar responden muslim). Berdasarkan tanggapan mereka, dapat dianalaisis bahwa pengetahuan menstruasi bagi kalangan siswa SDNegeri Prawoto 01 terlebih khususnya bagi kelas besar seperti kelas IV, V dan V masih tergolong rendah. Rendahnya Pengetahuan menstruasi mereka disebabkan tiga faktor.

Pertama, peran pendidikan dalam lingkungan keluarga belum mampu terlaksana dengan baik. Hal ini dikarenakan keluarga belum memperkenalkan pengetahuan menstruasi kepada buah hatinya. Sebagian besar orang tua juga memiliki pemikiran bahwa umur 9 tahun siswa belum pantas untuk diajak diskusi mengenai menstruasi. Padahal pada waktu tersebut adalah masa awal siswamenuju masa remaja yang tidak menutup kemungkinan siswa tersebut mulai mengalami menstruasi sebagai salah satu tanda-tanda pubertas remaja. Satu sisi keluarga merupakan pemberian pendidikan seks terkuat bagi siswa dan memiliki pengaruh terkuat dalam mengembangkan nilai-nilai seksual dan pemahaman seks pada remaja (Proverawati, 2009).

Kedua, guru belum memaparkan secaradetail mengenai ulasan materi organ reproduksi yang mengarah pada pengetahuan menstruasi. Guru merupakan orang tua kedua setelah ibu bapak (keluarga) siswa.Kerja sama antara guru dan keluarga diperlukan untuk menunjang pemahaman siswa tentang ilmu seksualitas terutama tentang menstruasi yang lebih kompleks. Berdasarkan hasil penelitian, materi organ reproduksi yang membahas bab menstruasi masuk dalam mata pembelajaran Ilmu Pengetahuan Alam (IPA) kelas V. Sebagian besar siswa kelas V dapat menerima materi organ reproduksi tersebut. Akan tetapi, tidak sedikit pula siswa yang belum memahami secara detail tentang bab pembahasan menstruasi. 
Berdasarkan Tabel 2 menjelaskan bahwa 90\% siswa kelas V tidak mengetahui tentang menstruasi, 5\% di antaranya menjawab mengetahui dan 5\% yang lainnya menjawab sedikit mengetahui. Hal ini berbeda dengan hasil pengisian angket dari kelas IV yang menunjukkan senayak 48\% siswa tidak memiliki pengetahuan tentang menstruasi. Presentase ini lebih sedikit dibandingkan dengan presentase siswa $\mathrm{V}$ mengenai ketidaktahuan tentang menstruasi. Perbedaan presentase ini dipengaruhi guru kelas (wali kelas) IV yang memaparkan bab menstruasi di sela-sela mata pelajaran IPA dan agama. Namun, tidak semua siswa dapat menagkapnya dan memahami materi tersebut.Perubahan wali kelas dari tahun ke tahun mempengeruhi pengetahuan siswa antar kelas.

Keterbatasan informasi pengetahuan siswa tentang menstruasi seperti Tabel 2 sebanyak $14 \%$ mengetahui menstruasi dan 35\% mengetahui sedikit menstruasi sangat dipengaruhi oleh orangtua dan guru. Berdasarkan hasil penelitian seperti Gambar 1 ini didapatkan bahwa sebagian besar 37 siswa memilih orang tua sebagai sumber termudah dalam mencari informasi menstruasi, kemudian diikuti sumber informasi menstruasi berikutnya guru sebanyak 12 siswa, buku sebanyak 8 siswa, internet sebanyak 4 siswa dan teman sebanyak 2 siswa. Sebagian besar siswa SD Negeri Prawoto 01 memilihnya, karena orang tua dianggap lebih dekat dengan mereka. Oleh karena itu orangtua dan guru memberikan peran yang besar dalam mendidik menstruasi, karena dianggap sebagai sumber informasi yang mudah diperoleh

\section{Sumber Informasi yang Mudah Diperoleh}

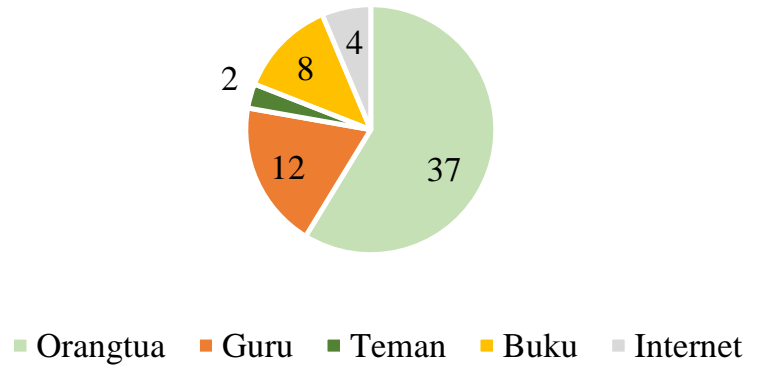

Gambar 1. Sumber Informasi Menstruasi yang Mudah diperoleh Menurut Siswa 
Ketiga, pengetahuan menstruasi berasal dari pengalaman menstruasi oleh siswa. Berdasarkan tabel 1, sebagian besar siswa (89\%) belum memiliki pengalaman tentang menstruasi. Pengalaman ini menjadi salah satu faktor yang memperngaruhi rendahnya pengetahuan siswa terhadap menstruasi. Ketika siswa telah mengalami menstruasi, siswa akan mencari tahu tentang apa yang telah terjadi dalam tubuhnya. Meskipun dengan malu-malu, siswa akan menanyaknnya pada kedua orang tuanya tentang apa yang terjadi pada dirinya. Bagi siswa yang belum mengalami menstruasi, tidak akan terlintas dalam fikirannya untuk mencari tahu tentang menstruasi.

Secara teoritis bahwa menstruasi adalah proses keluarnya darah melalui saluran vagina yang terjadi secara alami pada tubuh perempuan. Siklus ini merupakan proses organ reproduksi yang berfungsi untuk mempersiapkan terjadinya kehamilan apabila terjadi pembuahan. Persiapan tersebut dapat ditandai dengan penebalan dinding rahim (endometrium) yang berisi banyak pembuluh darah. Apabila tidak terjadi pembuahan, endometrium akan meluruh melalui vagina. Siklus tersebut berjalan selama selama 3-4 minggu. Awal siklus dimulai dari waktu hari pertama menstruasi hingga pada hari pertama menstruasi berikutnya.

Siklus menstruasi diatur oleh lima jenis hormon, di antaranya adalah hormon estrogen, progesteron, FSH (folice stimulating hormone), GnRH (gonadotropin relasing hormon), dan LH (luteinizing hormine). Menurut Marianti (2017) berdasarkan perubahan kondisi rahim dan konsentrasi hormon, siklus mentruasi dibagi menjadi empat fase di antaranya adalah sebagai berikut.

1. Fase Menstruasi

Fase mesntruasi merupakan fase pertama dari siklus menstruasi. Fase ini ditandai dengan peluruhan dinding rahim yang berisi banyak pembuluh darah dan lendir dengan presentase $2 / 3$ darah kotor dan 1/3 berupa lendir.

2. Fase Folikular

Fase folikular terjadi ketika hipotalamus di otak mengeluarkan hormon GnRH yang berfungsi untuk mernagsang kelenjar hipofisis (pituitari) untuk mengeluarkan hormon FSH. Setelah itu, hormon FSH akan 
merangsang ovarium (indung telur)untuk membentuk folikel-folikel yang berisi sel telur yang belum matang. Folikel tersebut akan berkembang selama kurang lebih 16-20 hari. Folikel yang telah matang akan mengeluarkan hormon estrogen yang kemudian terjadilah penebalan pada dinding rahim.

3. Fase Ovulasi

Fase ovulasi terjadi ketika ovarium melepaskan sel telur yang telah matang. Sel telur akan keluar dari ovarium pada saat kadar LH dalam tubuh mencapai optimal. Sel telur yang telah keluar akan menuju rahim untuk yang siap dibuahin oleh sel sperma. Apabila tidak dibuahi, sel telur akan melebur dalam waktu 24 jam. Waktu ovulasi biasanya berkisaran 1315 hari setelah masa menstruasi.

4. Fase Luteal

Fase ini terjadi ketika folikel yang telah mengeluarkan sel telur matang berubah menjadi jaringan korpus luteum. Korpus luteum akan mengeluarkan hormon estrogen dan progesteron yang berfungsi untuk menjaga dinding rahim tetap dalam keadaan tebal. Sehingga, uterus tetap kuat untuk menampung sel telur jika dibuahi. Jika terjadi pembuahan, tubuh akan memproduksi hormon HCG (Hormon Chorionic Gonadotropin) yang bertugas untuk mencegah terjadinya peluruhan korpus luteum pada dinding rahim. Namun, apabila tidak terjadi pembuahan, korpus luteum akan meluruh. Akibatnya, kadar estrogen dan progesteron dalam tubuh mengalami penurunan. Penurunan kedua kadar tersebut akan menyebabkan dinding uterus mengalami peluruhan dan terjadilah menstruasi. Fase luteal biasanya terjadi dalam kurun waktu 1117 hari dengan rata-rata 14 hari lamanya. Maka masa menstruasi normal berkisar dalam kurun waktu 3-7 hari. Akan tetapi, siklus menstruasi antara satu dengan lainnya berbeda. Siklus menstruasi dapat datang lebuh cepat atau lebih lambat. Hal ini dipengaruhi oleh faktor umur, gaya hidup (lifestyle), hormon dan pola makan.

Pengetahuan tentang menstruasi menjadi penting bagi siswa untuk menghadapi masa manarche. Manarche adalah awal terjadinya menstruasi. Nagar 
dan Aimol (2010) menyatakan bahwa pengetahuan siswa mengenai menstruasi dapat mempengaruhi persepsi siswa ketika mengalami masa awal menstruasi. Apabila persepsi yang diterima positif maka akan terbentuk kesiapan mental dalam menghadapi masa menstruasi pertama. Persepsi positif dalam hal ini adalah siswa yang memiliki pemahaman bahwa menstruasi awal yang dialaminya adalah suatu hal yang wajar atau normal dan secara emosi serta psikologi, siswa dapat menerimanya dengan baik. Begitupun sebaliknya apabila persepsi siswa tentang awal menstruasi yang diterima negatif, maka akan berujung pada ketidaksiapan mental dalam mengadapi masa awal menstruasi. Hal ini ditandai dengan rasa cemas, takut ketika mengalami masa awal menstruasi dan beranggapan bahwa menstruasi adalah suatu hal yang tidak wajar.

Pengetahuan menstruasi juga dilakukan oleh Afifah \& Hastuti (2016) menunjukkan bahwa 61,80\% siswa SD Negeri Dangkel Parakan Temanggung memiliki pengetahuan yang cukup baik atau dapat dikatakan tinggi. Perbedaan hasil penelitian ini dipengaruhi oleh faktor keluarga, sekolah dan lingkungan. Secara umum remaja putri sebagian besar memiliki pengetahuan tentang menstruasi karena kerjasama yang baik antara keluarga dan sekolah yang telah menyampaikan ulasan materi menstruasi kepada siswanya serta adanya faktor lingkungan yang mendukung.

Pendidikan menstruasi memang perlu diperkenalkan sejak usia sekolah dasar, karena berkaitan dengan kesehatan awal organ reproduksi. Menurt Kismiyati dkk (2016) bahwa pengetahuan reproduksi menjadi penting bagi siswa untuk mengenali kesehatan organ reproduksi, kelainan organ reproduksi dan juga tentang menstruasi. Terlebih bagi siswa yang telah mengalami menstruasi dan telah memasuki masa pubertas (baligh).

Berdasarkan penelitian Gustina \& Djannah (2015) juga memberikan dukungan fakta, bahwa ibu adalah sumber informasi dan pendukung terbaik selama masa pubertas. Akan tetapi, hanya sedikit para ibu yang menggambarkan pengalaman baik dan mengkomunikasikan tentang menstruasi dalam kehidupan sehari-hari. Selain peran orang tua, guru juga memiliki konstribusi terbesar kedua. Intensitas tatap muka guru dan murid hampir setiap hari menjadikan posisi guru sebagai orang tua siswa sekolah. 


\section{SIMPULAN}

Berdasarkan hasil penelitian dapat diambil kesimpulan bahwa sebagian besar siswa kelas IV, V dan VI dengan presentase $51 \%$ tidak memiliki pengetahuan tentang menstruasi. Hal ini menandakan bahwa pengetahuan mereka tentang menstruasi masih sangat minim. Hasil penelitian dari pengalaman menstruasi menunjukkan bahwa rata-rata $11 \%$ siswa SD telah mengalami menstruasi dengan rincian mulai kelas IV sebanyak 13\%, kelas V sebanyak 5\% dan kelas VI sebanyak 15\%. Siswa memperoleh kemudahan infomasi tentang menstruasi terbanyak berasal dari orang tua dan guru, informasi lain bersumber dari buku, internet dan teman. Pengenalan infomasi menstruasi sebaiknya sudah disiapkan dimulai kelas IV SD sejak masuk usia berkisar 9-10 tahun. Oleh sebab itu diperlukan pendidikan menstruasi di Sekolah Dasar dengan melibatkan peserta didik, guru, orangtua dan dukungan literatur buku bacaan yang relevan.

\section{DAFTAR PUSTAKA}

Afifah, Anisatun \& Hastuti, Tulus P. (2016). Hubungan Tingkat Pengetahuan tentang Menstruasi dengan Kesiapan Menghadapi Menarche pada Siswi Kelas V dan VI SD Negeri Dangkel Parakan Temanggung Tahun 2014. Jurnal Kebidanan. Vol. 5, No. 11.

Amelia, Coryna Rizky. (2014). Pendidikan Sebaya Meningkatkan Pengetahuan Syndrom Premenstruasi pada Remaja. Jurnal Kedokteran Brawijaya. Vol. 28, No. 2.

Desideria, Benedikta. (2017). Penyebab Anak Menstruasi Pertama di Bawah Usia 10 Tahun. https://m.liputan6.com/helath/read/2967192/3/penyebab-anakmenstruasi-pertama-di-bawah-usia-10-tahun. diakses tanggal 10 Agustus 2019.

Fajri, A. \& Khairani M. (2011). Hubungan antara Komunikasi Ibu-Anak dengan Kesiapan Menghadapi Menstruasi Pertama (Menarche) pada siswi SMP Muhammadiyah Banda Aceh. Jurnal Psikologi Undip. Vol. 10, No. 2.

Frediman, Marilyn. 2003. Keprawatan Keluarga, Teori dan Praktik. Jakarta: EGG. 
Gustiana, Erni \& Djannah, Siti Nur. (2015). Sumber Informasi dan Pengetahuan tentang Menstruasi Hygiene pada Remaja Putri. Jurnal Kesehatan Masyarakat. Vol. 10, No. 2.

Kusmiarti, Merta I \& Bahri S. (2016). Studi Pengetahuan tentang Menstruasi dengan Upaya Penanganan Disminore pada Mahasiswa Pendidikan Biologi. Jurnal Pijar MIPA. Vol. XI, No. 1.

Marianti. (2017). Menstruasi. https://www.alodokter.com/menstruasi.

Nagar. S. \& Aimol R. (2010). Knowledge of Adolescent Girls Regarding Menstruation in Tribal Areas of Meghalaya. Journal Vol. 8, No. 1.

Nurmawati, Ida \& Erawani, Feby. (2018). Tingkat Pengetahuan Menstruasi dalam Menunjang Kesiapan Siswi Menghadapi Menarche. Jurnal Kesehatan Masyarakat Andalas. Vol. 12, No. 1.

Proverawati, A \& Maisaroh S. (2009). Manarche, Menstruasi Pertama Penuh Makna. Yogyakarta: Medika Yogyakarta.

Pujiati, Wasis, Ernawati E, Daratulaila. (2017). Kecemasan Menghadapi Menarche pada Siswi Sekolah Dasar. Jurnal Medisains. Vol. 13, No. 1.

Triyanto, Endang. (2010). Pengalaman Masa Pubertas Remaja Studi Fenomenologi di Purwokerto. Jurnal Ners. Vol. 5 No. 2. 